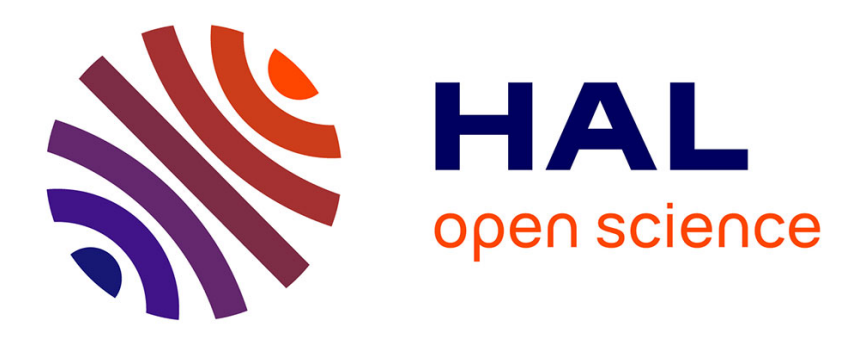

\title{
Smart \& Sustainable Mobility in a Complex Urban Context
}

Sabine Darmaillacq Chardonnet

\section{To cite this version:}

Sabine Darmaillacq Chardonnet. Smart \& Sustainable Mobility in a Complex Urban Context. IET International Conference on Smart and Sustainable City (ICSSC 2011), Jul 2011, Shanghai, China. 10.1049/cp.2011.0317 . halshs-01730917

\section{HAL Id: halshs-01730917 https://shs.hal.science/halshs-01730917}

Submitted on 13 Mar 2018

HAL is a multi-disciplinary open access archive for the deposit and dissemination of scientific research documents, whether they are published or not. The documents may come from teaching and research institutions in France or abroad, or from public or private research centers.
L'archive ouverte pluridisciplinaire HAL, est destinée au dépôt et à la diffusion de documents scientifiques de niveau recherche, publiés ou non, émanant des établissements d'enseignement et de recherche français ou étrangers, des laboratoires publics ou privés. 


\title{
Smart \& Sustainable Mobility in a Complex Urban Context
}

\author{
Sabine Chardonnet Darmaillacq \\ Ecole Nationale Supérieure d'Architecture Paris-Malaquais \\ sabine.chardonnet@wanadoo.fr
}

\begin{abstract}
The resistance to urban sprawl, the energy and social limits linked to the culture of acceleration and the aging of urban populations change the context and frameworks of thought about metropolitan mobility. In this context, and considering the impact of information technologies and sustainable concern, we propose a hypothesis for the city of the XXIst century as the "city of convergence", with the help of connectivity and shared intelligence. Mobility is our main point of consideration to understand these transformations. To reach and figure the complexity of urban context, we need to consider the urban territory in terms of strata or layers: ground, infrastructures, social networks and information. Within the double principle of convergence (input) and co-operation (output), we associate two questions for a hypothesis concerning livable city. How can public space remain friendly and interactive? Could walking become a new value and a collective urban intelligence for mobility?
\end{abstract}

\section{Introduction}

The resistance to urban sprawl, the energy and social limits linked to the culture of acceleration [16] and the aging of urban populations change the context and frameworks of thought about metropolitan mobility. It is accepted that the distribution of the energy bill and the control of air emissions regarding the developments of public facilities, housing and transport becomes an important factor in the conception of the sustainable city. Each mode of mobility shapes the territory. The elastic limits of moving are already exceeded in terms of stress of movement, household finances and communities, and urban sprawl.

In this context, and considering the impact of information technologies and sustainable concern, we propose a hypothesis for the city of the XXIst century as the "city of convergence", with the help of connectivity and shared intelligence. Mobility is our main point of consideration to understand these transformations.

\section{New values of mobility}

Mobilities are a relevant entry point and a good indicator of evolutions in urban society. Lifestyles and mobilities engender a new geography of territories, at the very moment when digital society is displaying information and offering new chains of services. It is interesting to understand how these service value gains can guarantee an access for all in the urban space, while associating in the best possible way technological developments to legible and welcoming spatial form.

Looking at mobility leads to references concerning changes of technical, ecological and economic systems, as to those of the lifestyles and ways of inhabiting territories. Mobility demands to be understood in term of choice rather than obligation, as a creation of links more than as simple crossing of distances. Unmotorized mobility, which substitutes the active mode for logistics, is the core of these representations and practices. Nevertheless few research projects and design projects take these hypotheses as an entry-point.

How can we develop the inter-relationship of OBJECT / SUPPORT / SERVICE for mobility? The city / mobility coupling demands a new balance in a context of radical change required in order to reach the "smart" and the sustainable.

Conventional planning tends to assume that transport progress is linear, with newer, faster modes replacing older, slower modes. Infrastructures remain specialized and autonomous even as they change. The architecture of infrastructures is too often isolated and monofunctional (silo-buildings, not communicating actors, different status of spaces) and tends to resist innovation. Digital technology now favors their decompartmentalization. The traditionnal meaning of transport network is that of a canal and flow. But when taking into consideration multimodality in large urban stations, we can measure a shift from a pipe and flow model to a synaptic approach, allowing new images and languages to appear.

However, all-pervasiveness of car versus a new notion of auto-mobility still have to be looked at. We are probably witnessing at present the end of an 
automobile period which began in the United States 70 years ago. The urban form of the second half of XXth century was dictated by the car. That of XXIst could be the form of intermodality and information, the primacy of modes over lines, where pedestrian mobility will see its role amplified as a common denominator of travel modes and stem cell of mobility, according to the prospectivist George Amar's expression [3].

We should also take into account John Urry's hypothesis according to which « we are witnessing a shift from communities based on the link between places to communities based on links between persons, facilitating the development of what Rheingold qualifies as " intelligent crowds " ». In light of this, we will consider innovation through the use and the empowerment of the mobile city-dweller. "There will be an increased convergence between transport and communication, mobilizing requirements and characteristics of copresence. [...] a person-to-person connectivity » [18].

"Mover" and "Homobile" are two figures of the mobile citizen :

Acting his own mobility, the "Homobile" is deciding for himself and is an autonomous mobility generator. He masters his time and values his autonomy, he is investigating, resting, roaming, visiting... The courted user or "Mover" is a client of mobility operators or economic actors, those who provide services, help in navigation, attractiveness, performance.

\section{Smart and/or sustainable mobility}

Mobility is side-stepped from transport and concerned with accessibility. In this enlarged consideration digital networks offer access to employment, shopping, sociabilities... If e-shopping, teleworking, co-working belong to the field of mobility, they affect territorial organization and lifestyles. But a question remains : how does digital technology impact ways of life and public space?

Urban digital resources should neither conceal citizen's expectations, nor postpone sustainability injunction, but stand at their disposal. What about connected urban development? Social value tends to disappear from some sustainable projects that call up for digital technologies : when forgetting about access inequalities, or assigning people to home work or homesourcing to escape relocation... a green technocratisation or quantitative optimization can mask social expectations. Digital resources offer opportunities for answering urban and territorial challenges, but we have to pay attention to social value.

According to Hartmut Rosa [16], time has been neglected in the analyses of modernity at the benefit of a process of rationalization and individualization, whereas time and its acceleration enable the comprehension of modernity. He buids a theory of social acceleration capable of developing a convergent thinking of technical acceleration (transports, communication), social change acceleration (lifestyles, familial structures) and acceleration of rythm of life, where lack of time and stress are manifest.

Traditional analysis of information systems depended upon signal processing and a processing center. Urban design cannot depend anymore upon accumulation of hardware and communication supplies, as we now figure information as a cloud.

When the public authorities, acting as planner/organizer/administrator, are on the orbit and while the citizen is empowered or gaining autonomy (Urbanism 2.0), roles become less stable between planners, generators, and actors of mobility. City 2.0 is a vision of a collaborative city using digital or non digital tools, bringing together citizen consultation, call for innovative ideas and involvment of the local community into urban planning projects.

Transport networks have been resulting durably from a top-down system of planification, design and management. Nowadays, a new traveller appears, more autonomous and willing to manage his mobility (choice, time and mode). With cloud information (open source, open stock, decentralization) and intangible assets 2 (investigations and public data, proximity, confidence, cooperation, security), we will not consider anymore the couple density + flow, but we aim for urban intensity and beat as at interconnections.

Bottom-up design is aiming at facilitating self organization emergence or proposals, planners and designers being questionned by collective intelligence, instant data, citizen participation, user generated content and the association of cognitive and practical aspects of public space use. Synergy, meshing, diversity and activated tracks are generating another spatial and social organization. Co-working areas, urban services, yield management, co-mobility, cycle or car-sharing are examples of emerging "soft infrastructure".

\section{A complex context of urban stratification: a multi-layered urbanity}

To reach and figure the complexity of urban context, we need to consider the urban territory in terms of strata or layers:

1. the layer of the ground, the territory and the geography, the ecosystem, that is what holds things together,

2. the durable layer of the networks of infrastructures and public facilities (water, 
energy, transport, housing), which nurtures and regulates the city,

3. the shifting layer of social networks, that lives and renews urban life,

4. the invisible layer of immaterial networks, conveying the information as a shared resource and nurturing the exchange.

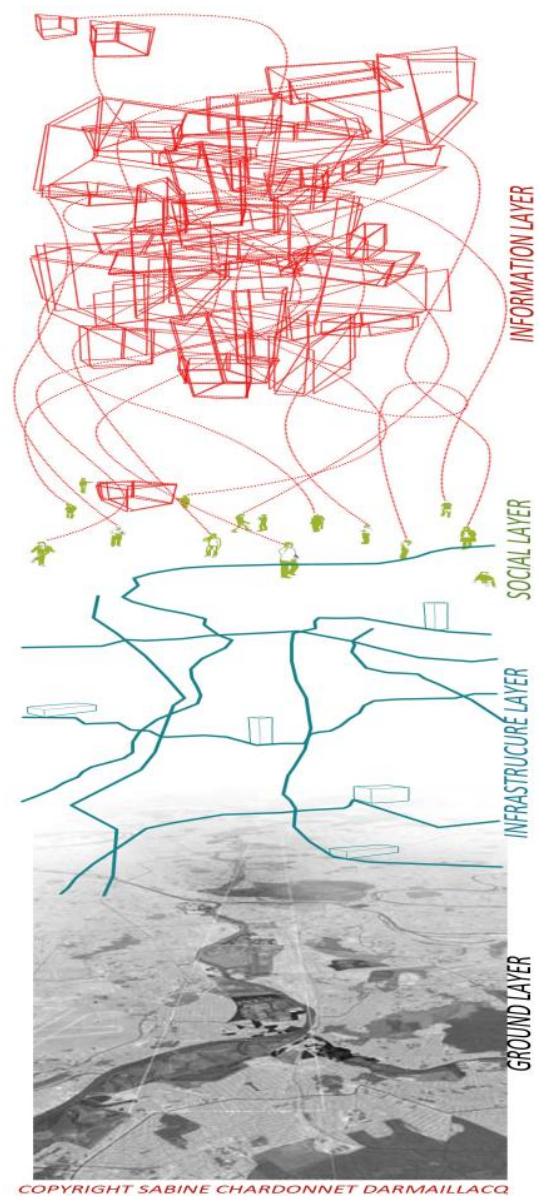

Fig 1- A multi-layered territory (C) SCD

According to such a device, the complex set of spatial, temporal, social practices and forces is difficult to represent and to model. Considering a given area, it is impossible to superimpose or merge all layers of information on a single surface or map, as there is no metric correspondance, nor common language in these urban data. To make a design process possible on such a territory without sacrificing this complexity, we propose the following hypothesis : in certain points of these layers we can read all together a set of informations or forces, thus bringing to the foreground the notion of acupuncture or nodal points (according to the image of a core drilling of soil through its multiple coats). In each of these specific cores, forces will have variable influence expanse per layer, as in a nervous system. We can work with this set of forces or data acting together in this core, in this moment when they are legible, co-present and active. Analysing forces or designing from such an acupuncture point or core allows in fact to act on a much more expanded territory, as through a nervous impulse or system, in accordance with the vertical orientation at the interface of layers and the horizontal orientation refering to relationship or binding.

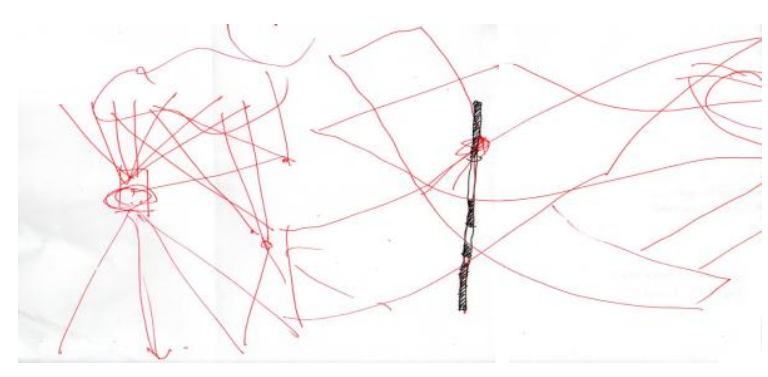

Fig 2 - Core exploration of forces in a multi-layered environment (C) SCD

\section{Livable city}

We associate two questions for a hypothesis concerning livable city. How can public space remain friendly and interactive? Could walking become a new value and a collective urban intelligence for mobility ? The double principle of convergence (input) and cooperation (output)

Considering temporal de-synchronisation of cities, walking seems to be a more nimble, realistic and rapid answer to the increasing demand of mobility, than the costly and long term development of transport infrastructures. Adherence, attachment and convergence are renewed values of the walkable city, to regard the development of a livable city. Walking invites us at the core of metropolitan urbanity and connections, the walker being transmodal. With his head for empowerment and legs for embodiement, he will gain mobility and sociability and come accros cultural diversity. Basket shoes and smartphones are emblematic of active mobility, that is flexible and self-organized. Intuitive connivance meeting rational knowledge, that of infrastructures, will reconstruct travel sequences associating "allotechniques" and "'homeotechniques" ${ }^{1}$.

Walking versus territories, density and decompaction: the nearest and the distant, embodied and virtual, obligatory or chosen time, required mobility or demobility are not opposite but completing in mentalities. Urban form is reversible and becomes the subject of alternating representations of compacity and intervals, according to uses that can be desynchronized or delocated.

Third places (cafés, co-working spaces, stations) and City Break reveal new behaviors. The City Breaker is seeking for routine's interruption, roaming, between anticipation and planification, surprise and

\footnotetext{
${ }^{1}$ Pierre Veltz's statement, at Colloque de Cerisy 2010 « la ville réversible ».
} 
unpredictable. He reformats information.

\section{PIGEWE : Convergence for Persons, informations, goods, ecosystem, waste, energy}

A factor 6 corresponds to decoupling between demographic growth and urban sprawl in Parisian Metropolitan area. Measuring ecological, financial and social impacts of investment choices for public space and infrastructures must be addressed. Overinvestment for infrastructures that are unwieldy, isolated and have a strong ecological footprint, is not convincing.

We need to think collective, "Co-mobility". Convergent mobility can be designed assuming a mobility synchronisation for persons, goods, information and waste. Short circuit of logistics can be considered, bringing together local resources in a convergent perspective, to redesign a distribution or retailing network, thta will connect the "mover" and the freight, rail and footpath, data and management. For the last hectometer, this system for travellers and freight has to find mobile and street furniture.

\section{A walk HUB as a key signature of sustainable mobility}

Connecting architecture of the territory, that of proximity and contiguity and digital network, 'SUCH' (Sentiers Urbains, Connexions et Hub pour la marche, Sabine C. Darmaillacq's project, for Paris 2030) is a system aiming at operational autonomisation of citizens and can be stated with 3 components :

- a town trails meshing, dedicated to walkability and exchange, as a first step for a territorial link network

- a set of nodal or acupuncture points where data and in formations are co-active, also being places for amenities an services, offering climatical and physiological comfort. A meshed set of these points underlies the mobility networks.

- a Hub for mobility and walking, associating physical and digital. It carries out reallocation of mobilities, amongst which walking, that pollinates urban life and territory. Imaginary, synergy and knowledge energy circulates in this system.

Solutions for a reversible mobilty, together individual and collective are transscalar. The Walk Hub is a participative and collaborative structure, a bottom up innovation linked with a cloud system, able to offer micro-scale solutions. It is composed within 3 scales :

- level 1: the mobility pole, that of stations or strong interconnection places, an infrastructure for walking, rhizome connected.

- level 2 : the mobility base, polyfunctional, permanent. It is a generator - relay for mobility and service, using feeding system of information, quality improvement loops, offering proximity and distance associations. Rhizome connected.

- level 3: mobile terminal or booth, ephemeral but connected relay for mobility and service. It is decentralized and adaptable according to cultural events or current affairs. Rhizome connected.

This last component could be housed on our smartphone's networks, but we assume that a human mediator is really valuable to permit access for all and to provide amenities. We are thus replacing the human being at the core of the system, psychological and cognitive aspects being central for the development and fulfillment of autonomous and collective mobility.

Beyond its first role for mobility service, the system could be considered in case of accident or crisis : central systems possibly being jammed or locked, information could benefit bottom up capillarity and be conveyed through this rhizome. This was experienced a few months ago when Washington was blocked by snow, with the emergence of a collaborative map showing real time problems and helping security service intervention $^{2}$.

\section{CONCLUSION}

Serendipity of urban walking practice or unmotorized mobility is all the more achievable if we can predict or foresee step by step adaptation. This is made possible by the combined presence of a physical, social, informational network. A new perspective in enrichment of urban exchanges is foreseen, when enlarging the point of view and considering the citizen together with the infrastructure/productive city, the suprastructure /city of knowledge and ecostructure /city as milieu [15].

The City of the XXIst century could gain from being the City of convergence. Convergence, confluence, converging... all terms for a renewed consideration of individuals or citizens, acting networks and institutions, converging to produce together a livable city, with the help of connectivity.

Our cities and territories are a collective interaction milieu, aiming at catering for a diversity of city dwellers. The City of the XXIst century cannot stand anymore on cartesianism and deterministic juxtapositions or additions of reclusive solutions where each solution would be a solitary answer to one controlled problem, according to the concept of cause and effect decomposition. The complexity of an

${ }^{2}$ Snowmageddon, Site Crowdsources, Blizzard Cleanup", Wired Magazine, 2010/02/10. Quoted by De Franqueville C., in Urbanisme, jan-fev. 2011, n 376, p60. 
organization, therfore, generally cannot be described or recomposed from its simple elements. Grasping reality is then more difficult ${ }^{3}$.

When a large number of causes exist side by side, things often happen in a way that may at first seem chaotic and irrational. But on closer inspection we perceive that, right from the start, reality engenders a summary form that emerges from the complexity of causes. This is what is called "self-organization, the effects of which have been demonstrated in biological structures as well as in human society [14]. This selforganization sometimes expresses itself in terms of adaptationand is easily discernible in the usage of an urban form or the equilibria of urban life. Designers or planners have often failed to foresee things would turn in the way they have, and users would unconsciously impose an organization that would prove very difficult to modify post factum. As though this organization was responding to a very powerfull logic. The habits of a place are not easily changed [7].

\section{Considering Smart \& Sustainable City helps us thinking differently :}

We used to have neighbours, we now have close friends or associates within a distance. We need to develop collective urban intelligence that generates dialogue between different worlds: prospects of the present, and its links with expertise and research [9].

The relation Man / Nature is not any more that of domination after Descartes, as it used to be for a long time now. Opposition between body and machine, or body and technique is unproductive. It seems advisable to postulate a connection, based upon reality and background, between body and city not as a awareness of the body into the city but as an awareness of the body with the city and its technologies of communication.

The need to resist urban sprawl, to deal with energy and resources limits, to change our view on the relation Man / Nature / Technology, is calling for a new consideration of convergence and cooperation of the three of them. Collective or transgenerational convergence does not impair individual fulfillment, but to the contrary.

\footnotetext{
${ }^{3}$ LAPLACE (1174) Exposé du déterminisme : " The present state of Nature's system is obviously a sequel to what it was immediately before, and if we conceive of an intelligence which, at any given moment, embraces all the interrelations between creatures and this Universe, then such an intelligence will be able to determine the relative positions, the movements, and the affections in general of all these creatures at any timewhatever in the past or in the future." Pierre-Simon LAPLACE Mémoires, Paris, 1774.

VOLTAIRE : "It would indeed be curious that all nature, all the planets, were subject to etrenal laws, and that one small animal 1.65 metre tall could behave as he thinks proper and according to his whim, despite those laws." (Quoted by Stewart, 1989, p181, Les Mathématiques, Paris, Pour La Science, Belin. Trad of The problems of Mathematics, Oxford University Press, 1987.
}

These positions enable considering the city or territory formation not as a collocation of infrastructure networks, eachone with its own logic and economy, but according to the point of view of convergence. Systems as the Walk HUB (or SUCH) are established since this essential idea of convergence.

\section{REFERENCES}

1. Allemand S., Ascher F., Levy J. ( dir ), Les sens $d u$ mouvement, Colloque de Cerisy, Institut de la Ville en Mouvement, Belin, 2004.

2. Amar G., Homo Mobilis, du transport urbain au nouvel âge de la mobilité, FYP, Limoges, 2010.

3. Amar G., Mobilité, urbanité, génération numérique, in Urbanisme jan-fev. 2011, n 376, p50.

4. Chardonnet Darmaillacq S., Colloque "Prendre Soin", Nouvelles perspectives de la marche métropolitaine: le marcheur dans l'action, la connaissance et le milieu, 18 juin 2010, Cerisy, 2011, (to be published).

5. Chardonnet Darmaillacq S., Colloque "Infraville" du LIAT, SUCH Paris 2030, Enjeux d'une infrastructure de marche, 17 octobre 2010, Paris, 2011, (to be published).

6. Chardonnet Darmaillacq S., Colloque "Abitare il Futuro", SUCH, une hypothèse de la condition mobile, 14 décembre 2010, Naples, 2011, (to be published).

7. Chardonnet Darmaillacq S., Maarek M., Form versus forces, in "Companion to contemporary architectural thought", London, New York, Ed. Routledge, 1993, pp268-277.

8. Chardonnet Darmaillacq S., 6 Feet Under, explorations artistiques sur le mouvement et le temps dans 2 parkings de la Saemes, video $12 \mathrm{~min}$, ENSAPM, 2010

9. Heurgon E., Annales de la recherche urbaine, $\mathrm{n}^{\circ} 104$ 2008, pp129-136.

10. Joseph, I., L'espace public comme lieu de l'action. Les Annales de la Recherche Urbaine, $\mathrm{n}^{\circ} 57 / 58,1992$, pp. 210-217.

11. Kaplan D., Marcou T., La ville 2.0 plateforme d'innovation ouverte, FYP, Limoges, 2008.

12. Kaplan D., Marzloff B., Pour une mobilité plus libre et plus durable, FING, FYP, Limoges, 2008

13. Levy J., « Ville pédestre, ville rapide », in Urbanisme, n³59, 2008, pp. 57-59.

14. Milgram, M., in Dupuy, J.P. (ed) L'autoorganisation, Colloque de Cerisy (1983), Seuil, Paris, 1985

15. Nijkamp P., Infrastructure, suprastructure and ecostructure : a portfolio of sustainable growth potentials. ftp://zappa.ubvu.vu.nl/1999, 0051.pdf.

16. Rosa H., Accélération, une critique sociale du temps, ED. La Découverte, Paris, 2010.

17. Urry J., " Mobility and proximity », in Sociology, $\mathrm{n}^{\circ} 36,2002$.

18. Urry J., Systèmes de la mobilité, Center for Mobilities Research, Lancaster University, in Cahiers internationaux de sociologie, 2005/1( $\left.\mathrm{n}^{\circ} 118\right)$.

19. Urbanisme, Aires numériques, $\mathrm{n}^{\circ} 376$, jan-feb 2011, Paris. 